\title{
Pelatihan Pembuatan Bahan Ajar Online Berbasis Web Pada SeKolah Menengah KeJURUan Negeri 1 Tanah Miring
}

\author{
${ }^{1}$ Syamsul Bahri, ${ }^{2}$ Merta Simbolon, ${ }^{3}$ Abraham Laurens Rettob
}

\author{
${ }^{1,2}$ Pendidikan Fisika, Universitas Musamus, Merauke, Indonesia \\ ${ }^{3}$ Pendidikan Kimia, Universitas Musamus, Merauke, Indonesia \\ email: ${ }^{1}$ syamsul_fkip@unmus.ac.id, ${ }^{2}$ simbolon_fkip@unmus.ac.id, 3abraham@unmus.ac.id
}

\begin{abstract}
SMK Negeri 1 Tanah Miring is one of the schools whose lessons have been affected by the Covid-19 pandemic. The main problem faced by teachers at SMKN 1 Tanah Miring is the lack of accessible teaching materials in the learning process, especially online teaching materials during the Covid-19 pandemic. The purpose of this training is to provide knowledge and training to teachers on various types of online teaching materials that can be developed with the web. This training and mentoring are carried out in the form of presentations, training, and mentoring, both through face-to-face and online activities so that at the end of the activity it is hoped that you will know about online learning and various online teaching materials. The results of the evaluation of the activities showed that the majority of the participants, who were all teachers of SMK Negeri 1 Tanah Miring, were very satisfied with the implementation of this activity. However, the results of the evaluation of the impact of these activities indicate that the activities that have been implemented have been ineffective. Even though $88 \%$ of teachers managed to have their website address, only $10 \%$ of them managed to develop their website content according to the subject they were teaching.

Keywords: Online Teaching Materials, Web-Based learning, Learning During the Covid-19 Pandemic
\end{abstract}

\begin{abstract}
Abstrak. SMK Negeri 1 Tanah Miring merupakan salah satu sekolah yang pembelajarannya terdampak pandemi Covid-19. Masalah utama yang dihadapi oleh guru di SMKN 1 Tanah Miring adalah minimnya bahan ajar yang dapat diakses dalam proses pembelajaran, khususnya bahan ajar online pada masa pandemi Covid19 ini. Tujuan pelatihan ini adalah memberikan pengetahuan dan pelatihan kepada guru tentang berbagai jenis bahan ajar online yang dapat dikembangkan dengan web. Pelatihan dan pendampingan ini dilaksanakan dalam bentuk presentasi, pelatihan, dan pendampingan, baik melalui kegiatan tatap muka maupun secara online sehingga pada akhir kegiatan diharapkan sudah memiliki pengetahuan tentang pembelajaran online serta berbagai bahan ajar online. Hasil evaluasi kegiatan menunjukkan bahwa mayoritas peserta kegiatan yang seluruhnya terdiri atas guru SMK Negeri 1 Tanah Miring sangat puas terhadap pelaksanaan kegiatan ini. Hal ini dapat dilihat dari $88 \%$ guru yang berhasil memiliki alamat website sendiri. Namun, jika dilakukan evaluasi terhadap dampak kegiatan ini bagi peserta di dalam melaksanakan aktivitasnya di sekolah, hanya 10\% dari mereka yang berhasil mengembangkan konten websitenya sesuai dengan mata pelajaran yang diajarkannya. Oleh karena itu, dapat disimpulkan bahwa kegiatan yang telah dilaksanakan tidak efektif.

Kata Kunci: Bahan Ajar Online, Pembelajaran Berbasis Web, Pembelajaran Masa Pandemi Covid-19
\end{abstract}

\section{Pendahuluan}

Distrik Tanah Miring merupakan salah satu daerah tujuan transmigrasi yang terletak di Kabupaten Merauke, Propinsi Papua. Secara teritorial, Merauke masuk sebagai salah satu wilayah perbatasan NKRI, yaitu daerah 
terdepan dan terluar yang berbatasan langsung dengan daratan negara lain (Bappenas, 2014).

Selain pada sektor pertanian yang baik di daerah ini, juga tersedia akses pendidikan yang baik. Secara umum, sekolah pada Distrik Tanah Miring dapat diakses lebih mudah jika dibandingkan dengan beberapa sekolah pada distrik lain. Selain keterjangkauannya, jaringan internet pada Distrik Tanah Miring juga sangat mendukung, khususnya bagi sekolah.

Sekolah Menengah Kejuruan (SMK) Negeri 1 Tanah Miring adalah salah satu sekolah yang terletak di Satuan Pemukiman 7 (SP7), Tanah Miring yang berjarak kurang lebih 22 KM dari pusat kota. Adapun bidang keahlian utama pada sekolah ini adalah sesuai dengan potensi lokal wilayah tersebut, yaitu pertanian.

Secara umum, siswa pada sekolah di Merauke sangat beragam, baik dari warga Papua asli yang biasa disebut dengan OPA (Orang Papua Asli), warga pendatang atau warga transmigrasi dari luar Papua, seperti dari Jawa, Sulawesi, Sumatera, dan Nusa Tenggara Timur. Bahkan, beberapa sekolah memiliki siswa dari negara tetangga, yaitu Papua Nugini. Hal ini juga berlaku pada siswa SMK Negeri 1 Tanah Miring.

Jumlah peserta siswa pada SMK Negeri 1 Tanah Miring tahun ajaran 2019/2020 adalah 419 siswa dengan jumlah laki-laki adalah 229 laki-laki dan perempuan sebanyakk 190 orang. Jumlah rombongan kelas pada SMK Negeri 1 Tanah Miring adalah 17 orang dengan kegiatan pembelajarannya diselenggarakan pada pagi hari. Sekolah ini memiliki jumlah guru sebanyak 27 orang (Kementerian Pendidikan dan Kebudayaan, 2020).

Pembangunan berbagai bidang di wilayah Kabupaten Merauke, seperti bidang kelautan, pertanian, dan industri tidak lepas dari dukungan Universitas Musamus sebagai salah satu lembaga pendidikan tinggi dan pengembang ilmu pengetahuan. Dukungan tersebut telah dituangkan di dalam Rencana Strategi Universitas Musamus pada tahun 2016. Implementasi dari rencana strategis tersebut salah satunya dapat dilakukan melalui kegiatan pengabdian masyarakat, baik masyarakat produksi ekonomi maupun nonproduktif, seperti sekolah dan sejenisnya dengan berbagai skim. Sumber pendanaan kegiatan tersebut dapat bersumber dari DIPA Universitas Musamus dan dari DRPM Kementerian Pendidikan dan Kebudayaan.

Penyelenggaraan kegiatan pengabdian pun dapat dilakukan dalam berbagai bentuk. Idealnya, sebuah kegiatan pengabdian yang dilakukan adalah hasil dari penelitian dosen di kampus, khususnya yang berbentuk aplikasi teknologi untuk pengembangan kampung-kampung sesuai potensi daerah dan lokal di Kabupaten Merauke dan sekitarnya (LPPM Unmus, 2016). Pendidikan di sekolah merupakan salah satu cara yang paling efektif digunakan oleh pemerintah dalam rangka mencapai tujuan pendidikan secara nasional. Oleh karena itu, perlu diperhatikan peranan dari masingmasing komponen yang terletak pada ujung tombak pendidikan sekaligus penentu dan indikator kualitas pendidikan, yaitu guru dan siswa. Dalam konteks pendidikan hari ini, siswa merupakan orang yang diajar dan menerima berbagai jenis materi tentang bagaimana melakukan rekayasa teknologi, sedangkan guru adalah orang yang mengajarkan tentang bagaimana melakukan hal yang telah diajarkan kepada siswa tersebut. Namun demikian, hasil penelitian yang dilakukan terhadap guru dan calon guru fisika di Kabupaten Merauke, khususnya di daerah perbatasan menunjukkan masih 
rendahnya pemanfaatan berbagai macam teknologi informasi dan komunikasi (TIK) di dalam proses pembelajaran di kelas (Bahri, Waremra, Reski, Silubun, \& Rettob, 2019; Bahri \& Waremra, 2018).

Pengetahuan dan kemampuan guru di dalam memanfaatkan TIK di dalam pembelajaran di kelas dapat dilihat pada Gambar 1. Gambar tersebut memperlihatkan bahwa kemampuan guru dan calon guru fisika terhadap pemanfaatan berbagai TIK masih sangat rendah. Hal ini tentunya menjadi masalah bagi guru yang akan berdampak pada siswa sehingga perlu dilakukan pelatihan dalam rangka meningkatkan kemampuan tersebut. Salah satu kegiatan yang dapat dilakukan adalah pelatihan terhadap pengembangan bahan ajar online yang berbasis web bagi guruguru. Pelatihan ini dilaksanakan di SMK Negeri 1 Tanah Miring sebagai implementasi dari penelitian dan pengembangan bahan ajar yang dikembangkan oleh pemateri.

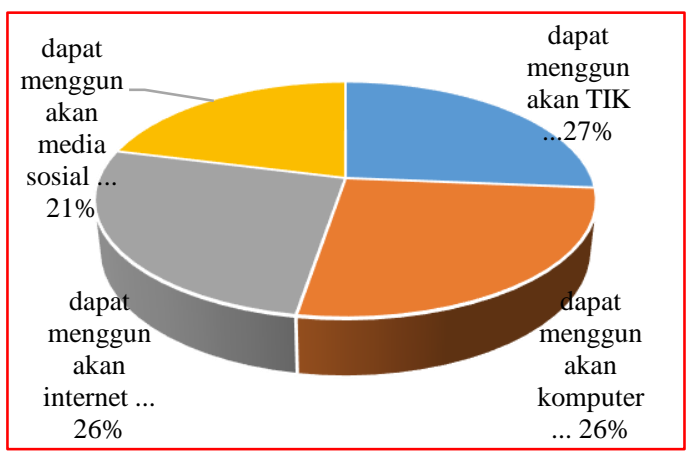

Gambar 1. Kemampuan memanfaatkan TIK dalam pembelajaran

Sumber: (Bahri et al., 2019)

Era revolusi industri 4.0 sebagaimana yang berlangsung saat ini telah memaksa guru untuk terus melakukan pengembangan diri serta penyesuaian terhadap berbagai perubahan yang terjadi, khususnya di dalam teknologi pembelajaran. Hal tersebut sangatlah penting mengingat pendidikan sebagai salah satu tahap dalam kehidupan manusia sehingga tentunya akan memberikan dampak pada masa depan anak-anak didiknya (Yahya, 2018).

Bukti nyata yang dapat dilihat dari pentingnya guru dalam menguasai teknologi, khususnya teknologi pembelajaran adalah ketika dunia dilanda masa pandemi Covid-19 seperti saat ini. Secara umum, kegiatan pelatihan media pembelajaran, khususnya yang berbasis web dapat meningkatkan kemampuan profesionalisme guru dalam mengoperasikan media pembelajaran elektronik (Kurniawan et al., 2021). Oleh karena itu, kegiatan pelatihan pengembangan bahan ajar online berbasis web sangat penting untuk dilakukan saat ini karena dapat membantu guru dalam mempersiapkan pembelajaran secara online. Selain itu, pelatihan ini juga dapat mengembangkan pengetahuan teknologi dan pedagogik (technological pedagogical knowledge, TPK) guru.

\section{Metode Ilmiah}

Kegiatan pengabdian ini diselenggarakan dengan menggunakan tiga metode, yaitu metode pelatihan, metode pendampingan, dan evaluasi produk kegiatan. Pelaksanaan kegiatan dengan menggunakan metode pelatihan dibantu oleh mahasiswa yang sekaligus sebagai pembantu lapangan dalam mendukung kelancaran kegiatan ini. Mahasiswa mendampingi peserta kegiatan, dalam hal ini guru pada saat dan setelah materi kegiatan disampaikan oleh pemateri. Pemateri yang membutuhkan bantuan akan langsung ditangani oleh mahasiswa. Namun, jika masalah yang dihadapi oleh siswa tidak dapat dipecahkan oleh mahasiswa, barulah pemateri membantunya. Namun, jika jumlah peserta yang meminta bantuan lebih banyak daripada jumlah 
mahasiswa, pemateri tetap akan membantu peserta.

Peserta yang mengikuti kegiatan pelatihan ini terdiri dari beberapa unsur, yaitu kepala sekolah, guru, staf sekolah, siswa, dan mahasiswa yang secara keseluruhan berjumlah 38 orang dengan jumlah pemateri adalah 2 orang dosen. Meskipun ada beberapa unsur yang mengikuti kegiatan ini, pemateri tetap memfokuskan kegiatan pada sasaran utama kegiatan ini, yaitu kepada 29 orang guru. Target utama yang ingin dicapai pada guru adalah meningkatnya kemampuan mereka di dalam mengembangkan bahan ajar yang berbasis web.

$$
\text { Kegiatan pelatihan ini }
$$

dilaksanakan di SMK Negeri 1 Tanah Miring, tepatnya pada ruangan aula kegiatan. Seluruh persiapan kegiatan dilakukan oleh guru dan staf di sekolah tersebut demi lancarnya pelaksanaan kegiatan. Selain itu, seluruh fasilitas yang diperlukan juga telah disiapkan dengan baik, seperti tata ruang kegiatan, LCD, pencahayaan, dan fasilitas pendukung lainnya.

PowerPoint merupakan media utama yang digunakan di dalam kegiatan pelatihan ini. Seluruh materi kegiatan disampaikan dengan menggunakan media PowerPoint. Selain media ini sederhana, PowerPoint menjadi salah satu bagian dalam pengembangan materi online, yaitu pada pengembangan materi PowerPoint secara online dengan menggunakan Google Slides pada Google Drive.

Pemanfaatan Google Slides di dalam pelatihan ini bukanlah alasan utama penggunaan Google Drive. Ada banyak hal yang dapat dilakukan dengan penggunaan Google Drive, seperti melatih guru untuk mengembangkan materi pembelajaran dengan menggunakan Google Docs secara kolaboratif serta pemanfaatan google form di dalam melakukan evaluasi pembelajaran. Namun, hal yang paling penting sebagai pertimbangan di dalam menggunakan Google Drive ini adalah penggunaan Google Sites, yakni bahan ajar yang dikembangkan oleh guru akan berbasis web, baik dengan menggunakan Google Sites tersebut maupun dengan menggunakan hosting dari pemateri. Google Drive ini sangat bermanfaat selama pelatihan berlangsung karena peserta dapat melakukan praktik pembuatan bahan ajar secara langsung tanpa membutuhkan setting domain yang lama jika dibandingkan dengan penggunaan subdomain pada hosting pribadi pemateri.

$$
\text { Materi kegiatan pelatihan }
$$

meliputi Technological Pedagogical Content Knowledge (TPACK) Guru, Pembelajaran Berbasis Web, Pemanfaatan Media Sosial dalam Pembelajaran, Aplikasi Pendukung Pembelajaran Online, seperti Google Slide dan Google Site. Materi tersebut dipilih untuk memperkuat pemahaman guru, baik dari segi konsep dan teori bahan ajar maupun dari segi praktik dalam pengembangan bahan ajar online. Jadi, tidak hanya membuat materi begitu saja, tetapi peserta, khususnya guru mengetahui secara keseluruhan tentang bahan ajar online berbasis web.

Materi TPACK merupakan suatu pengetahuan yang sangat penting untuk dimiliki oleh guru yang terkait dengan kemampuannya mengintegrasikan antara pengetahuan teknologi, pengetahuan pedagogis, dan bidang ilmu yang dimilikinya dalam mencapai tujuan pembelajaran secara khusus dan tujuan pendidikan secara umum. Materi TPACK yang disampaikan di dalam kegiatan pelatihan meliputi tujuh aspek utama, yaitu Technological Knowledge (TK), Pedagogical Knowledge (PK) Content Knowledge (CK), Technological Pedagogical Knowledge (TPK), Technological Contentent Knowledge (TCK), Pedagogical Content 
Knowledge, dan Technological Pedagogical Content Knowledge (TPACK).
Secara singkat, program utama serta indikator keberhasilan program dapat dilihat dalam Tabel 1.

Tabel 1.

Program Kegiatan dan Indikator Keberhasilan

\begin{tabular}{|c|c|c|c|}
\hline No. & Program & Indikator Utama Pencapaian & $\begin{array}{c}\text { Persentase } \\
\text { Penilaian } \\
\text { Maksimum (\%) }\end{array}$ \\
\hline 1 & $\begin{array}{l}\text { Pelatihan penentuan } \\
\text { domain dan hosting } \\
\text { gratis dan becarbayar }\end{array}$ & $\begin{array}{l}\text { Peserta kegiatan dapat menentukan nama domain } \\
\text { serta hosting secara gratis dan berbayar }\end{array}$ & $10 \%$ \\
\hline 2 & $\begin{array}{l}\text { Pelatihan pembuatan dan } \\
\text { pengunggahan materi secara } \\
\text { online }\end{array}$ & $\begin{array}{l}\text { Peserta kegiatan dapat membuat materi, baik } \\
\text { dalam bentuk word, pdf, PowerPoint, gambar, } \\
\text { maupun video; dan mengunggahnya secara online }\end{array}$ & $20 \%$ \\
\hline 3 & $\begin{array}{l}\text { Pelatihan pembuatan tes online } \\
\text { dengan Google Form }\end{array}$ & $\begin{array}{l}\text { Peserta kegiatan dapat mengembangkan tes online } \\
\text { dengan Google Form }\end{array}$ & $20 \%$ \\
\hline 4 & $\begin{array}{l}\text { Pelatihan memadukan media } \\
\text { sosial dengan pembelajaran } \\
\text { online }\end{array}$ & $\begin{array}{l}\text { Peserta dapat memadukan media sosial dengan } \\
\text { pembelajaran online }\end{array}$ & $20 \%$ \\
\hline 5 & $\begin{array}{l}\text { Pendampingan pengembangan } \\
\text { dan pengelolaan bahan ajar } \\
\text { online berbasis web }\end{array}$ & $\begin{array}{l}\text { Peserta kegiatan dapat mengembangkan dan } \\
\text { mengelola bahan ajar online berbasis web }\end{array}$ & $30 \%$ \\
\hline
\end{tabular}

Perkembangan teknologi dan informasi yang semakin pesat juga diiringi oleh perkembangan media sosial. Oleh karena itu, pelatihan ini juga menyampaikan materi tentang berbagai media sosial yang dapat dijadikan sebagai media pembelajaran, khususnya pada masa pandemi seperti saat ini. Di antara media sosial yang dibahas dalam pelatihan ini adalah media sosial Facebook (FB), Messenger, WhatssApp (WA), Line, dan Telegram. Masingmasing dari media sosial tersebut memiliki kelebihan yang dapat dimanfaatkan di dalam pembelajaran online.

Bahan ajar serta pembelajaran online yang berbasis web perlu didukung oleh fasilitas yang memadai, namun tetap dapat dijangkau oleh pengguna, khususnya guru. Salah satu fasilitas yang disediakan oleh Google adalah Google Drive. Setiap orang yang memiliki satu akun Google akan mendapatkan ruang penyimpanan online sebesar 15 GB. Ruang penyimpanan yang cukup besar ini dapat digunakan oleh pengguna untuk menyimpan berbagai file-file yang dianggap penting. Google Slide dan Google Site yang disedikan oleh Google di dalam Google Drive dapat dimanfaatkan oleh guru untuk mengembangkan bahan ajar maupun sistem pembelajaran online. Sebagai contoh, guru yang tidak memiliki keahlian di dalam membangun website dengan domain dan hosting yang mahal dapat memanfaatkan Google Site sebagai media publikasi bahan ajarnya dengan mengintegrasikan Google Form sebagai sistem evaluasinya.

Guru yang telah memperoleh materi di dalam kegiatan pelatihan akan didampingi oleh pemateri dan mahasiswa. Tujuan dari kegiatan tersebut adalah untuk memberikan bekal dan pengalaman teknik tentang penyusunan dan pengembangan web sederhana, khususnya dengan menggunakan Google Site. Pada kegiatan ini, seluruh guru akan dibuatkan satu akun/domain dengan menggunakan 
Google Site. Selanjutnya, pemateri akan menjelaskan langkah demi langkah dalam mengembangkan bahan ajar online-nya dengan pendampingan.

Jadi, selain teori dari materi pelatihan yang dilakukan, pendampingan ini juga memberikan bekal bagi guru tentang praktik penggunaan website. Praktik yang dimaksud adalah mulai dari pembuatan akun Gmail oleh guru, pembuatan website pada Google Site, cara memasukkan materi pembelajaran, cara melakukan publikasi, sampai pada cara mengakses materi tersebut oleh siswa.

Seluruh website guru yang telah dibuat dengan menggunakan Google Site dapat diakses melalui 1 portal utama pemateri, yaitu melalui domain http://www.dosenmuda.com. Selain menggunakan Google Site, beberapa guru yang tidak berhasil melakukan publikasi materi melalui google site juga melakukan publikasi materi dengan menggunakan Google Slide.

Kegiatan selanjutnya yang dilakukan oleh tim adalah melakukan evaluasi terhadap kegiatan yang telah dilakukan. Evaluasi kegiatan ini dilakukan tepat setelah pelaksanaan kegiatan selesai. Tujuan kegiatan evaluasi ini adalah untuk melihat gambaran umum kegiatan mulai dari awal hingga akhir. Manfaat yang dapat diambil adalah sebagai bahan refleksi di dalam melakukan kegiatan sejenis pada waktu yang akan datang, baik dari pemberian materi, pemataeri, fasilitas kegiatan, maupun pada konsumsi selama pelaksanaan kegiatan. Kegiatan evaluasi ini dilakukan dengan melakukan penyebaran angket kepada seluruh peserta kegiatan. Adapun aspek yang dievaluasi meliputi beberapa aspek, di antaranya 1) metode dan media, 2) relevansi dan kemanfaatan, 3) fasilitas pelatihan, 4) konsumsi, dan 5) pemateri.

Pada aspek metode dan media yang digunakan terdapat lima butir pernyataan yang menunjukkan tingkat kepuasan peserta terhadap metode yang digunakan, kesesuaian media pelatihan dengan kondisi sekolah, ketersediaan dan kualitas media, ketersediaan dan ketepatan penyediaan modul. Aspek relevansi dan kemanfaatan juga terdiri atas lima butir pernyataan yang melihat bagaimana keterkaitan dan manfaat dari kegiatan ini dengan pelaksanaan tugas guru dalam kehidupan sehari-hari. Sementara itu, aspek fasilitas pelatihan meliputi ketersediaan sarana/prasarana yang dibutuhkan di dalam kegiatan pelatihan. Jumlah butir pernyataan dalam aspek ini terdiri atas 5 . Keseluruhan butir pernyataan dari 5 aspek yang diukur terdiri atas 30 butir pernyataan.

Berdasarkan jumlah butir pernyataan, skala penilaian dan jumlah peserta akan menanggapi angket ini, maka kategorisasi respons peserta diperlihatkan pada Tabel 2.

Tabel 2.

Kategorisasi Respons Peserta Kegiatan

\begin{tabular}{lcc}
\hline \multicolumn{1}{c}{ Kategori } & Rumus & $\begin{array}{c}\text { Rentang } \\
\text { Skor }\end{array}$ \\
\hline $\begin{array}{l}\text { Kurang } \\
\text { memuaskan }\end{array}$ & $\mathrm{X} \leq \mathrm{M}-1 \mathrm{SD}$ & $\mathrm{X} \leq 60$ \\
$\begin{array}{l}\text { Cukup } \\
\text { memuaskan }\end{array}$ & $\mathrm{M}-1 \mathrm{SD}<\mathrm{X}$ & $60<\mathrm{X} \leq 75$ \\
$\begin{array}{l}\text { Memuaskan } \\
\mathrm{M}<\mathrm{X} \leq \mathrm{M}+\end{array}$ & $75<\mathrm{X} \leq 90$ \\
$\begin{array}{l}\text { Sangat } \\
\text { memuaskan }\end{array}$ & $\mathrm{X}>\mathrm{M}+1 \mathrm{SD}$ & $\mathrm{X}>90$ \\
\hline
\end{tabular}

Evaluasi dampak kegiatan terhadap pemahaman dan pengetahuan peserta bertujuan untuk mengukur efektivitas pelatihan yang telah dilakukan terhadap pengetahuan dan pemahaman peserta. Adapun teknik analisis data yang digunakan adalah dengan menggunakan $N$-Gain, yaitu melihat selisih kemampuan peserta sebelum dan setelah dilaksanakan kegiatan. Secara matematis, N-Gain dapat dituliskan dalam Persamaan 1. 


$$
\mathrm{N}-\text { Gain }=\frac{\text { Skor Postest }- \text { Skor Pretest }}{\text { Skor Ideal }- \text { Skor Pretest }}
$$

Adapun kategori $N$-Gain dibuat dalam bentuk persentase dan dikategorikan berdasarkan Tabel 3.

Tabel 3.

\begin{tabular}{cl} 
Kategori Tafsiran Efektivitas $\boldsymbol{N}$-Gain \\
\cline { 2 - 2 } Persentase(\%) & Tafsiran \\
\hline$<40$ & Tidak efektif \\
$40-55$ & Kurang efektif \\
$56-75$ & Cukup efektif \\
$>76$ & Efektif \\
\hline
\end{tabular}

\section{Hasil dan Pembahasan}

Pelaksanaan kegiatan pengabdian kepada masyarakat ini dilaksanakan dengan tetap mengikuti protokol kesehatan pandemi Covid-19. Sebelum melaksanakan kegiatan ini, tim telah melakukan koordinasi dengan pihak sekolah tentang gambaran umum kegiatan sehingga pihak sekolah dapat mempersiapkan berbagai kebutuhan, khususnya yang mendukung pelaksanaan kegiatan ini dengan tetap menjaga protokol kesahatan.

Salah satu upaya yang dilakukan oleh tim untuk mengurangi interaksi antarpeserta adalah dengan menyelenggarakan kegiatan ini dalam dua bentuk, yaitu secara online (dalam jaringan/daring) dan offline (luar jaringan/luring). Pelaksanaan kegiatan secara offline atau tatap muka hanya dilaksanakan selama dua hari yang meliputi kegiatan pemberian materi utama serta pendampingan secara teknis tentang bagaimana membuat akun sampai pada tahap publikasi materi. Sementara itu, pelaksnaan kegiatan secara online juga dilakukan selama dua hari. Pada bagian ini, seluruh kegiatan dilaksanakan dan dipantau secara online melalui link web guru yang telah dibuat saat pelatihan hari pertama dan kedua.

Pelaksanaan kegiatan hari pertama dilaksanakan melalui tatap muka di aula SMK Negeri 1 Tanah Miring. Adapun kegiatan yang dilakukan pada hari pertama ini adalah dengan memberikan materi pengantar dan materi utama tentang bagaimana mengembangkan dan memublikasikan materi ajar secara online, khusunya pada masa pandemi saat ini.

Kegiatan pada hari pertama ini selain diikuti oleh guru, juga diikuti oleh beberapa orang siswa serta mahasiswa sebagai anggota tim pelaksana kegiatan. Namun demikian, sasaran utama tim pemateri tetaplah guru karena merekalah yang menjadi ujung tombak di dalam penyampaian materi ajar kepada siswa. Sementara itu, beberapa siswa yang ikut bertujun untuk mendapatkan pengetahuan serta pengalaman di dalam mengakses materi guru secara online dengan menggunakan website guru masing-masing.

Kegiatan hari pertama dilaksanakan pada tanggal 13 Oktober 2020 dengan materi yang dibawakan adalah Pengantar Pembelajaran Berbasis Web; Pengantar tentang Kemampuan TPACK; Pemanfaatan Media Sosial dalam Pembelajaran Online; Berbagai Aplikasi Pendukung Pembelajaran Online; dan materi tentang Pengembangan Bahan Ajar Online Berbasis Web.

Hari kedua dilaksanakan pada tanggal 14 Oktober 2020 dengan jenis kegiatan yang dilakukan adalah pelatihan dan pendampingan. Adapun kegiatan yang dilakukan adalah melakukan Pelatihan Pembuatan website/blog gratis dengan Menggunakan Blogger; Pelatihan Pembuatan website dengan menggunakan Google Site; dan pelatihan dan upload materi secara online. Selain kegiatan pelatihan dan pendampingan ini dilakukan oleh kedua pemateri, pelaksanaan kegiatan ini juga dibantu oleh mahasiswa sehingga pelaksanaan kegiatan dapat berjalan dengan lancar. 
Pada hari ketiga, jumlah peserta menurun secara drastis disebabkan tidak semua guru/peserta dapat melaksanakan kegiatan ini secara online. Namun demikian, kegiatan ini tetap terlaksana meskipun hanya diikuti oleh beberapa orang. Adapun kegiatan yang dilakukan pada hari ketiga adalah memberikan materi sekaligus praktik tentang pembuatan tes online dengan menggunakan Google Form serta pembuatan tes online dengan menggunakan aplikasi SiPanTer (https://www.sipanter.com).

Kegiatan hari keempat lebih kepada evaluasi dari kegiatan hari pertama sampai hari ini. Pada kegiatan hari ini, jumlah peserta mengalami peningkatan dari hari sebelumnya, namun tetap saja yang tidak hadir hampir dari separuh jumlah peserta. Pada akhir kegiatan ini, jumlah peserta tidak mengurangi waktu pelaksanaan kegiatan ini. Dalam kegiatan ini, hanya 23 orang guru yang berhasil memiliki domain atau alamat website pembelajaran secara pribadi, sedangkan 3 orang lainnya tidak berhasil karena berbagai kendala yang dihadapi.

Evaluasi kegiatan dilakukan tepat setelah kegiatan pelatihan dan pendampingan dilakukan. Adapun hasil evaluasi kegiatan dapat dilihat dalam Gambar 2. Dalam evaluasi kegiatan ini, ada 5 aspek yang diukur, yaitu metode dan media dengan persentase rata-rata respons peserta $83,9 \%$ (sangat memuaskan); relevansi dan kemanfaatan dengan persentase rata-rata respons peserta $69,4 \%$ (memuaskan); fasilitas diklat dengan persentase rata-rata respons peserta $79,8 \%$ (sangat memuaskan); konsumsi dengan persentase rata-rata respons peserta $76,2 \%$ (sangat memuaskan); dan pemateri dengan persentase rata-rata respons peserta $81,0 \quad$ (sangat memuaskan).
Pengukuran dampak dari kegiatan dilakukan melalui pemberian angket sebelum dan setelah pelaksanaan kegiatan. Hasil analisis terhadap angket tersebut memperlihatkan adanya peningkatan pengetahuan dan pemahaman peserta tentang pengembangan bahan ajar secara online yang berbasis web. Untuk melihat efektivitas kegiatan yang telah dilaksanakan, dilakukan analisis Normalized Gain (N-Gain) (Meltzer \& David, 2002). Hasil analisis N-Gain dapat dilihat dalam Tabel 3. Berdasarkan Tabel 3, rerata pesentase N-Gain masuk dalam kategori tidak efektif.

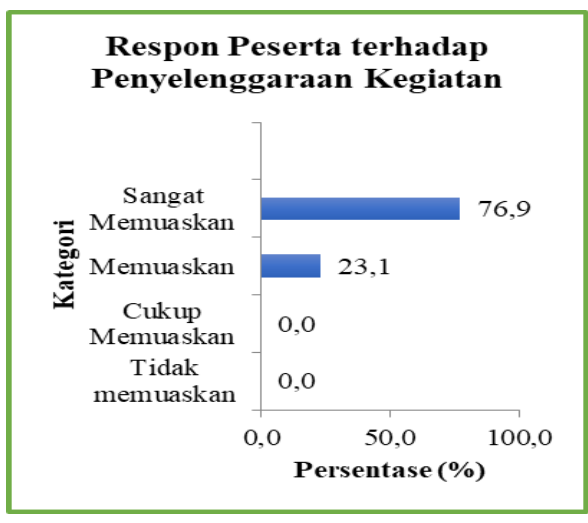

Gambar 2. Respons Peserta terhadap Penyelenggaraan Kegiatan

Secara umum, kegiatan ini berjalan dengan lancar berkat adanya dukungan dari semua pihak yang terlibat, khususnya kerja sama guru sebagai peserta pelatihan dan bantuan dari mahasiswa dalam pelaksanaan kegiatan. Hasil analisis kebutuhan menunjukkan bahwa selama ini guru hanya menggunakan media sosial Messenger dan WhatsApp secara terbatas dalam pembelajaran serta Zoom yang tingkat penggunaannya sangat rendah. Oleh karena itu, pelaksanaan kegiatan ini sangat didukung, terutama karena manfaatnya dalam situasi pandemi saat ini. Hal itu bukan semata kerena pandeminya, tetapi memang pembelajaran online saat ini sudah menjadi bagian yang sangat penting 
dalam proses belajar mengajar agar tetap dapat mengikuti perkembangan teknologi.

SMK Negeri 1 Tanah Miring merupakan salah satu sekolah yang selama ini selalu mendukung program kerja ataupun kegiatan dari Universitas Musamus, khususnya bagi Fakultas Keguruan dan Ilmu Pendidikan (FKIP). Oleh karena itu, kegiatan ini, semakin meningkatkan kerja sama antara sekolah dengan dosen pelaksana kegiatan secara personal dan dengan FKIP secara kelembagaan.

Hasil evaluasi pelaksanaan kegiatan menunjukkan bahwa mayoritas peserta kegiatan merasa sangat puas terhadap kegiatan yang telah dilaksanakan. Indikator yang memiliki skor paling besar adalah pada begian kemanfaatan kegiatan ini. Para peserta yang keseluruhannya adalah guru menganggap bahwa kegiatan ini dapat memberikan manfaat bagi guru, khususnya dalam pengembangan profesinya. Selain itu, para peserta juga sangat puas dalam penyampaian materi kegiatan, mulai dari penyajian materi yang baik sampai pada pemecahan berbagai masalah yang dihadapi oleh guru dalam pengembangan materi pembelajaran, khususnya pembelajaran online.

Selain respons peserta sangat puas terhadap pelaksanaan kegiatan, juga ada beberapa hal yang perlu diperhatikan dan diperbaiki pada kegiatan-kegiatan berikutnya yang sejenis dengan kegiatan ini. Hal yang dimaksud adalah penyediaan modul cetak yang perlu disiapkan lebih awal sebelum pelaksanaan kegiatan sehingga modul-modul tersebut dapat digunakan pada saat pelaksanaan kegiatan sedang berlangsung. Selain itu, hal lain yang perlu diperhatikan oleh pelaksana kegiatan, khususnya pemateri adalah mengefektifkan waktu kegiatan yang sudah dijadwalkan karena setiap peserta kegiatan akan mempersiapkan diri berdasarkan kegiatan yang telah dijadwalkan sebelumnya.

Hasil analisis data pretest (angket sebelum kegiatan) dan postteset (angket setelah kegiatan) tentang efektivitas pelaksanaan kegiatan ini menunjukkan bahwa $N$-Gain kegiatan ini masuk dalam kategori tidak efektif. Beberapa penyebab hal ini terjadi karena kemampuan guru dalam pembelajaran online, khususnya web sangat minim meskipun secara umum, kemampuan TIK guru masuk dalam kategori yang sangat baik. Hingga kegiatan pelatihan ini dilaksanakan, tenyata kemapauan khusus guru di dalam pembelajaran online masih rendah. Kurangnya pengetahuan guru dalam pembelajaran online salah satunya disebabkan oleh kebiasaan guru yang mengajar secara tatap muka. Selain itu, pelaksanaan kegiatan yang sangat terbatas karena adanya pandemi Covid-19, yaitu dengan metode tatap muka dan online membuat peserta sangat kesulitan dalam mengaplikasikan materi yang diperoleh dalam pelatihan dan pendampingannya.

Hasil atau produk dari kegiatan ini adalah website guru-guru SMK Negeri 1 Tanah Miring. Dari 26 orang yang aktif mengikuti kegiatan hingga akhir, hanya 23 orang guru yang berhasil memiliki domain atau alamat website pembelajaran secara pribadi yang seluruhnya dapat diakses pada website http://www.dosenmuda.com, sedangkan 3 orang lainnya tidak berhasil karena berbagai kendala yang dihadapi, khususnya masalah jaringan. Berdasarkan hasil monitoring pada 23 website tersebut, hanya sekitar $10 \%$ guru mengembangkan konten web sesuai dengan mata pelajarannya. Hal ini memperkuat hasil evaluasi terhadap dampak kegiatan yang telah dilakukan yang menunjukkan bahwa kegiatan ini tidak efektif. 
Dari hasil monitoring dan evaluasi terhadap keberlanjutan program ini, ditemukan berbagai masalah di lapangan yang menjadi penyebab sulitnya guru-guru mengembangkan halaman website yang mereka miliki. Adapun masalah-masalah tersebut adalah 1) Sulitnya jaringan internet pada beberapa guru, khususnya bagi guru yang berada pada lokasi tertentu yang tidak memiliki akses internet atau akses internetnya sangat sulit; 2) Situasi pandemi Covid-19 menyebabkan guruguru kesulitan untuk melakukan kerja sama melalui pertemuan tatap muka; 3) Guru masih membutuhkan pendampingan dari narasumber dalam pengembangan materi berbasis web.

Tabel 4.

\begin{tabular}{|c|c|c|c|c|c|c|}
\hline \multicolumn{7}{|c|}{ Hasil Analisis N-Gain } \\
\hline No. Peserta & Skor Pretest & $\begin{array}{c}\text { Skor } \\
\text { Setelah }\end{array}$ & $\begin{array}{c}\text { Skor Posttest - } \\
\text { Skor Pretest }\end{array}$ & $\begin{array}{l}\text { Skor Ideal - } \\
\text { Skor Pretest } \\
\end{array}$ & $\begin{array}{c}\text { Skor } N- \\
\text { Gain } \\
\end{array}$ & $\%$ Gain \\
\hline 1 & 10 & 20 & 10 & 30 & 0,33 & 33,33 \\
\hline 2 & 13 & 22 & 9 & 27 & 0,33 & 33,33 \\
\hline 3 & 16 & 19 & 3 & 24 & 0,13 & 12,50 \\
\hline 4 & 12 & 22 & 10 & 28 & 0,36 & 35,71 \\
\hline 5 & 14 & 21 & 7 & 26 & 0,27 & 26,92 \\
\hline 6 & 12 & 25 & 13 & 28 & 0,46 & 46,43 \\
\hline 7 & 16 & 23 & 7 & 24 & 0,29 & 29,17 \\
\hline 8 & 14 & 21 & 7 & 26 & 0,27 & 26,92 \\
\hline 9 & 16 & 21 & 5 & 24 & 0,21 & 20,83 \\
\hline 10 & 12 & 22 & 10 & 28 & 0,36 & 35,71 \\
\hline 11 & 13 & 23 & 10 & 27 & 0,37 & 37,04 \\
\hline 12 & 12 & 22 & 10 & 28 & 0,36 & 35,71 \\
\hline 13 & 17 & 21 & 4 & 23 & 0,17 & 17,39 \\
\hline 14 & 14 & 20 & 6 & 26 & 0,23 & 23,08 \\
\hline 15 & 14 & 21 & 7 & 26 & 0,27 & 26,92 \\
\hline 16 & 14 & 23 & 9 & 26 & 0,35 & 34,62 \\
\hline 17 & 16 & 23 & 7 & 24 & 0,29 & 29,17 \\
\hline 18 & 12 & 23 & 11 & 28 & 0,39 & 39,29 \\
\hline 19 & 14 & 22 & 8 & 26 & 0,31 & 30,77 \\
\hline 20 & 14 & 20 & 6 & 26 & 0,23 & 23,08 \\
\hline 21 & 15 & 21 & 6 & 25 & 0,24 & 24,00 \\
\hline 22 & 16 & 24 & 8 & 24 & 0,33 & 33,33 \\
\hline 23 & 13 & 20 & 7 & 27 & 0,26 & 25,93 \\
\hline 24 & 10 & 21 & 11 & 30 & 0,37 & 36,67 \\
\hline 25 & 12 & 22 & 10 & 28 & 0,36 & 35,71 \\
\hline 26 & 14 & 22 & 8 & 26 & 0,31 & 30,77 \\
\hline \multicolumn{6}{|c|}{ Rerata Persentase $N$-Gain } & 30,17 \\
\hline
\end{tabular}


Hal yang sama juga terjadi pada SMK Negeri 1 Sota, yakni hasil pelatihan menunjukkan bahwa kompetensi guru SMK Negeri 1 Sota dalam pemanfaatan TIK untuk kegiatan belajar mengajar masih masuk dalam kategori kurang sehingga diperlukan suatu proses pembiasaan dalam memanfaatkan TIK untuk kegiatan pembelajaran agar guru-guru semakin terlatih (Bahri et al., 2020).

Peningkatan kompetensi guruguru di daerah perbatasan seperti wilayah Merauke ini sangat penting untuk dilakukan, baik dari dinas terkait maupun oleh dosen melalui kegiatan Pengabdian kepada Masyarakat. Selain kepada guru, di sekolah perbatasan juga perlu dilakukan peningkatan kompetensi staf sekolah, peningkatan kualitas informasi siswa-siswi terkait dengan sosialisasi internet positif, serta perbaikan tata nilai masyarakat di bidang pendidikan melalui penerapan TIK (Maulana et al., 2020).

\section{Kesimpulan dan Saran}

Pelaksanaan kegiatan ini masih tergolong belum efektif. Hal ini dapat dilihat dari rendahnya hasil analisis terhadap $\mathrm{N}$-Gain serta persentase peserta yang mengembangkan konten web sesuai dengan mata pelajarannya hanya mencapai $10 \%$. Hal ini disebabkan oleh berbagai faktor, baik dari kemampuan guru, situasi pandemi Covid-19, maupun dukungan jaringan internet pada lokasi tertentu. Selain itu, guru-guru juga perlu didampingi dalam penyusunan dan pengembangan bahan ajar online sehingga ke depannya ketersediaan bahan ajar ini memudahkan proses pembelajaran online dan sebagai suplemen dalam pembelajaran tatap muka.

\section{Ucapan Terima kasih}

Penulis mengucapkan terima kasih kepada Rektor Universitas Musamus atas bantuan pendanaan melalui program DIPA Unmus dengan nomor kontrak 181.1/UN52.8/PM/2020. Terima kasih juga kami ucapkan kepada kapala sekolah dan guru-guru SMK Negeri 1 Tanah Miring atas kerja sama dan partsipasinya dalam kegiatan ini.

\section{DAFTAR PUSTAKA}

Bahri, S., Simbolon, M., Sari, D. K., \& Rettob, A. L. (2020). Pelatihan Penggunaan Fasilitas Google dalam Kegiatan Pembelajaran untuk Meningkatkan Kompetensi Pedagogik. ETHOS: Jurnal Penelitian Dan Pengabdian Kepada Masyarakat, 8(2), 205-211. https://doi.org/10.29313/ethos.v8i2. 5436

Bahri, S., \& Waremra, R. S. (2018). Skills for The Use of Information and Communication Technology Prospective Physics Teachers in Facing The Learning of The Industrial Revolution Era 4.0. 9(11), 28-36.

Bahri, S., Waremra, R. S., Reski, A., Silubun, H. C. A., \& Rettob, A. L. (2019). Early Conditions of Physics Learning Reviewed From Teacher Pedagogic Competencies in SMP Negeri 11 Merauke (RI-PNG Border Area). International Journal of Mechanical Engineering and Technology (IJMET), 10(02), 13911396.

http://www.iaeme.com/ijmet/issues. asp?JType $=$ IJMET $\&$ VType $=10 \&$ IT ype $=02$

Bappenas. (2014). Laporan Akhir: Kajian Evaluasi Program Pembangunan dan Pengembangan Kawasan Khusus dan Daerah Tertinggal. 
Hake, R, R. (1999). Analyzing Change/Gain Scores. AERA-D (American Education Research Association's Division D, Measurement and Reasearch Methodology. https://www1.physics.indiana.edu/ sdi/AnalyzingChange-Gain.pdf

Kementerian Pendidikan dan Kebudayaan. (2020). Sekolah Kita. http://sekolah.data.kemdikbud.go.id/ index.php/chome/profil/4fc73734cfa9-4948-aa7e-65d2f3ead33c

Kurniawan, C. S. A., Rokhim, D. A., \& Siddiq, I. H. Al. (2021). Pelatihan Pengoperasian Media PEembelajaran bagi Guru untuk Meningkatkan Profesionalitas Guru. ETHOS: Jurnal Penelitian Dan Pengabdian Kepada Masyarakat, 9(1), 36-43. https://ejournal.unisba.ac.id/index.p hp/ethos/article/view/6222/pdf

LPPM Unmus. (2016). Rencana Strategis Pengabdian Kepada Masyarakat. Lembaga Penelitian dan Pengabdian Kepada Masyarakat Universitas Musamus.

Maulana, I. T., Darwas, R., Rahimullaily, \& Ningsih, S. R. (2020). Peningkatan Kualitas Pendidikan di Daerah Terpencil Melalui Pelatihann dan Penerapan IPTEKS. 8(2), 305-312. https://ejournal.unisba.ac.id/index.p hp/ethos/article/view/5966

Meltzer, E., \& David. (2002). The relationship between mathematics preparation and conceptual learning gains in physics: A possible hidden variable in diagnostic pretest score. American Journal Physics, 70(12), 1259-1268.

https://doi.org/https://doi.org/10.111 9/1.1514215.

Yahya, M. (2018). Era Industri 4.0: Tantangan dan Peluang Perkembangan Pendidikan Kejuruan Indonesia. Sidang Terbuka Luar Biasa Senat Universitas Negeri Makassar. 